\title{
Investigation of mTOR, JAK/STAT, and Hedgehog pathways inhibitor effect on the proliferation of haematological cancer cell lines
}

\section{Roberta Vadeikiené $\dot{e}^{\star 1}$,}

Aistė Savukaitytè',

\section{Danguolè Laukaitiené $\dot{e}^{1}$,}

\section{Rasa Ugenskiené $\dot{1}^{1,2}$,}

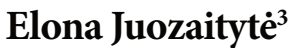

${ }^{1}$ Oncology Research Laboratory,

Oncology Institute,

Lithuanian University of Health Sciences,

Eiveniu St. 2, Kaunas 50161, Lithuania

\section{${ }^{2}$ Department of Genetics}

and Molecular Medicine,

Hospital of Lithuanian University

of Health Sciences Kaunas Clinics,

Eiveniu St. 2, Kaunas 50161, Lithuania

\section{${ }^{3}$ Department of Oncology}

and Haematology,

Hospital of Lithuanian University

of Health Sciences Kaunas Clinics,

Eiveniu St. 2, Kaunas 50161, Lithuania
Constitutively activated JAK/STAT signaling pathway is a common feature of the $B C R / A B L$-negative classic myeloproliferative neoplasms (MPN). JAK2 small-molecule inhibitors have been proven to be clinically efficacious; however, they are not mutation-specific and competent enough to suppress neoplastic clonal haematopoiesis. There is a need for exploring new therapeutic strategies for MPN. Additional signaling systems, such as $\mathrm{PI} 3 \mathrm{~K} / \mathrm{Akt} / \mathrm{mTOR}$ and Hedgehog, are a potential treatment target. The aim of this study was to characterise and compare the effects of specific JAK/STAT, PI3K/Akt/mTOR, and Hedgehog signaling inhibitors in haematological cell cultures. JAK2 p.V617F mutated SET-2 and JAK2 wild-type UT-7 human cell lines were employed in our study. The effect of specific signaling pathway inhibitors was studied as time- and dose-response experiments. Viability was measured by trypan blue exclusion and alamarBlue assays. IC50 values were used to compare the effectiveness of inhibitors in decreasing cell viability. Independent sample t-test was used for statistical comparisons between experimental groups. $p<0.05$ was considered significant. Our results indicate that all specific inhibitors progressively reduced the number of viable cells as the concentration and exposure duration increased. Inhibitors impaired the proliferation of JAK2 mutated cells at significantly lower doses compared to wild-type JAK2 cell line. These in vitro data indicate that JAK/STAT and alternative PI3K/Akt/mTOR and Hedgehog inhibitors have a potential anti-proliferative efficacy. Future studies, involving direct screening of PI3K/Akt/ mTOR, JAK/STAT, and Hedgehog signaling molecules activity, at gene and protein level in cell-based MPN model, are required.

Keywords: myeloproliferative neoplasms, JAK/STAT, PI3K/Akt/ mTOR, Hedgehog, signaling pathway, cell lines

\footnotetext{
* Corresponding author. Email: roberta.vadeikiene@lsmuni.lt
} 


\section{INTRODUCTION}

The $B C R / A B L$-negative classic myeloproliferative neoplasms (MPNs) that include polycythemia vera (PV), essential thrombocythemia (ET), and primary myelofibrosis (PMF) arise from a transformed haematopoietic stem or a progenitor cell resulting in overproduction of mature myeloid and erythroid progeny (Vannuchi et al., 2009; Grinfeld et al., 2017). Clinically, MPNs share the features of bone marrow hypercellularity, an increased risk of thrombosis or haemorrhage; incurable MPNs lead to reduced life expectancy and progression to acute leukaemia (Bartaluchi et al., 2017; Grinfeld et al., 2017). Generally, PV, ET, and PMF have undistinguishable clinical and laboratory features and are included as one entity in most trials.

It is known that MPN stem cells are defined as a clonal population of rare cells within the bone marrow that harbour an MPN-initiating somatic mutation. They are capable of indefinite self-renewal, and undergo expansion through a combination of cell intrinsic and cell-extrinsic effects. The molecular basis of MPN has been determined in almost all cases. MPN patients are characterized by a JAK2 p.V617F (exon 14) point mutation, which is present in $95 \%$ of patients with PV and in $50-60 \%$ of ET or PMF patients (Vainchenker et al., 2011; Klampfl et al., 2013). Furthermore, JAK2 exon 12 mutations are found in $2-3 \%$ of PV patients and $5-10 \%$ of ET and PMF patients are described by activating MPL mutations (Beer et al., 2008). Recently, researchers have declared that CALR 52-bp deletion and 5-bp insertion are present in majority of ET and PMF patients with nonmutated JAK2 or MPL (Klampfl et al., 2013; Nangalia et al., 2013; Andrikovics et al., 2014), which may play a role in the self-regeneration/proliferation of MPN haemopoietic progenitor cells, although direct contribution of CALR to the pathology of MPN is not fully clarified (Rotunno et al., 2014; Araki et al., 2016; Chachoua et al., 2016).

All mentioned molecular abnormalities play a crucial role in constitutive activation of JAK/ STAT signaling pathway. They contribute to cytokine hypersensitivity and cytokine indepen- dent growth of mutant cells, as exemplified by the endogenous erythroid colonies (EEC) typically found in most PV patients (Dupont et al., 2007). Retroviral, transgenic, and conditional knock-in mouse models revealed that the expression of JAK2 p.V617F mutation is sufficient to resume myeloproliferative neoplasms phenotype (Marty et al., 2010; Mullaly et al., 2010), suggesting the central role of JAK/STAT activation in MPN ethiopathogenesis. Consequently, aberrantly activated JAK/STAT has become an attractive target for MPN therapy. In preclinical models, ATP-competitive small-molecule JAK2 inhibitors prevented proliferation of JAK2 p.V617F mutant cells in vitro and mitigated myeloproliferation in JAK2 p.V617F transgenic animals (Quintas-Cardana et al., 2010; Vannucchi et al., 2011; Bogany et al., 2013; Bartaluchi et al., 2017). It was reported that JAK2 inhibitors were effective in patients with PMF, PV, and ET (Cevantes et al., 2012; Verstovsek et al., 2013). JAK2 can be inhibited by several drugs, including ATP-mimetic small molecule kinase inhibitors and histone deacetylase inhibitors. Recently, among JAK2 inhibitors, ATP-competitive ruxolitinib has been approved for the treatment of patients with myelofibrosis, and it is in a late-stage clinical trial for polycythemia vera (Harrison et al., 2012; Verstovsek et al., 2013). However, treatment with ruxolitinib is associated with only modest decrease in p.V617F allele burden and clinical responses were documented independent of JAK2 p.V617F mutation status (Bartaluchi et al., 2017). Most likely, this reflects a number of issues: (1) that inhibitors, yet developed, are not specific to mutant JAK2, and (2) that activation or its consequence is not the only pathogenic mechanism operating in MPN. To overcome possible limitations and drawbacks of ruxolitinib, novel molecules acting as ATP competitive inhibitors of the JAK2 ATP active site have been developed and evaluated in trials (Pardanani et al., 2009). Lately, good tolerance, decreased spleen size, and symptom reduction in MPN patients have been documented (Pardanani et al., 2013; Pardanani et al., 2015).

It is already known, that the pathogenesis of MPNs is very complex and other dysregulated 
signaling pathways may offer additional therapeutic targets. PI3K/Akt/mTOR signaling pathway is a key regulator of many cellular processes including cell survival, proliferation, and differentiation, and has been found hyperactivated in a large number of solid cancers and haematological malignancies. Moreover, a few years ago it was revealed that activation of JAK/STAT by JAK2 mutation in MPN is associated with increased signaling of PI3K/Akt/mTOR (Grimvade et al., 2009). Although PI3K/Akt/mTOR signaling pathway was found constitutively activated in JAK2 p.V617F mutated cells in vitro (James et al., 2005; Bumm et al. 2006) and in p.V617F transgenic (Shide et al., 2008) or knockin mice (Akada et al., 2010), the contribution of this signaling pathway to the ethiopathogenesis of MPN is not completely understood. Given the crucial role of the current signalling pathway, there is an intense interest in this field, and many molecules, as potential specific drug, are in different stages of clinical evaluations. The principal target of activated Akt is mTOR, which exists in two complexes, mTORC1 and mTORC2. TORC1, formed with raptor, controls the level of cap-dependent mRNA translation and phosphorylates effectors such as 4E-BP1 and S6K1. TORC1 is strongly inhibited by rapamycin and its derivate. S6K1 and its target eIF4E have been involved in cell transformation and are overexpressed in poor-prognosis cancers (Engelman, 2009; Gao et al., 2016). In several studies, the effects of mTOR inhibitors, either as a single drug or in combination with JAK2 inhibitors, in different cellular models and primary cells from MPN patient were evaluated. In vitro data indicated that everolimus, a rapamycin-derivate inhibitor (rapalog) of mTOR, is active against MPN cells and its combination with JAK1/2 inhibitors produced synergism (Vannucchi et al., 2011; Bogany et al., 2013; Bartaluchi et al., 2017). Recently, the mTOR inhibitor, everolimus, has been shown to exhibit clinical activity in phase I/II trial in patients with myelofibrosis (Wang et al., 2009; Guglielmelli et al., 2011). Hence, some experimental and clinical evidence indicating that $\mathrm{PI} 3 \mathrm{~K} / \mathrm{Akt} / \mathrm{mTOR}$ pathway could represent a therapeutic target in MPNs is presented.
Autonomous activated JAK2 has become a target for MPN therapy. Unfortunately, the therapeutic use of JAK inhibitors is limited due to the essential role of the JAK/STAT pathway in normal haematopoiesis. According to the literature, JAK2 inhibitors cause toxicities such as anemia and thrombocytopenia. Consequently, there is a need to find additional signaling pathways that can be associated with development and maintenance of MPN clones. Recent studies have shown that the Hedgehog (Hh) signaling pathway has an important role in normal haematopoiesis as well as in the pathogenesis of myeloid malignancies (Rimkus et al., 2016). Supposedly, Hedgehog signaling pathway, which plays a role in the maintenance of cancer stem cells, could provide an avenue for targeting stem cell-derived clonal myeloproliferation. Unfortunately, only few studies were reported so far (Bhagwat et al., 2013; Zingariello et al., 2013; Tibes, Mesa, 2014; Campbell, Copland, 2015). The experiments showed that expression of the Gli1 and Ptch1, Hedgehog signal molecules, are 20-100 times higher in granulocytes of MPN patients when compared with normal control cells. Researchers also observed activation of this pathway in a murine bone marrow transplant model of PMF (Bhagwat et al., 2013). According to this data, the Hedgehog pathway is active in primary samples of MPN patients and in preclinical models of PMF. A different murine model of PMF (Gata1 ${ }^{\text {low }}$ ) has shown alterations in the Hh pathway at the gene level in the bone marrow and spleen. Zingariello et al. (2013) suggested that components of the Hh pathway cooperate with TGF $\beta$, p53, and mTOR-related genes to produce the biological phenotype of PMF (Zingariello et al., 2013). Therefore, complexity of Hedgehog regulation provides a variety of cellular targets. While nearly all known Hh pathway antagonists target the transmembrane protein Smo, Hyman et al. (2009) reported that small molecules inhibitors acting downstream of Smo could constitute a more comprehensive strategy for treating $\mathrm{Hh}$ pathway-dependent tumours (Hyman et al., 2009). These findings illustrate challenges associated with identifying compounds that can block oncogenic Hh pathway 
activity. Taken together, all the data suggest that the Hh signaling pathway plays a role in haematologic malignancies, including MPNs, and its inhibition may block proliferation and progression of tumour cells.

In this study we explored the potent effect of targeting JAK/STAT, PI3K/Akt/mTOR, and Hedgehog pathways with specific inhibitors in vitro. We evaluated the effect of JAK1/2, mTOR and Gli1/Gli2 inhibitors as single drugs in two different cellular models. Experiments were carried out with cells expressing JAK2 p.V617F mutation. Cells with wild-type JAK2 were used as a control cell line.

\section{MATERIALS AND METHODS}

Reagents. RAD001 - everolimus (a mTOR specific allosteric inhibitor against TORC1) was purchased from Alfa Aesar (part of Thermo Fisher Scientific), Karlsruhe, Germany. CYT387 (ATP-competitive inhibitor of JAK1/JAK2) was obtained from Abcam, Cambridge, United Kingdom. HPI-1 (specific inhibitor with activity against Gli1/Gli2) was provided by Sigma-Aldrich, Taufkirchen, Germany. RAD001, CYT387 and HPI-1 were dissolved in sterile $100 \%$ DMSO to prepare $10 \mathrm{mM}$ stock solutions (the percentage of DMSO in experiments was lower than $0.5 \%$ ). Stocks were stored under light protected conditions at $-20^{\circ} \mathrm{C}$. Each stock was used only once by adding in culture medium.

Cell lines. The JAK2 p.V617F mutated SET-2 and JAK2 wild-type UT-7 human cell lines were purchased from the German Collection of Microorganisms and Cell Cultures (DSMZ, Braunschweig, Germany). Cell line authentication was done by DSMZ SET-2, cell line was cultured in RPMI-1640 (Sigma-Aldrich, Taufkirchen, Germany) supplemented with $20 \%$ foetal bovine serum, $100 \mu \mathrm{g} / \mathrm{ml}$ streptomycin, $100 \mathrm{units} / \mathrm{ml}$ penicillin, and $2 \mathrm{mM} \mathrm{L}$-glutamine (Gibco (part of Thermo Fisher Scientific), Carlsbad, CA, USA). The UT-7 cell line was maintained in alphaMEM (Sigma-Aldrich, Taufkirchen, Germany) supplemented with $20 \%$ foetal bovine serum, $100 \mu \mathrm{g} / \mathrm{ml}$ streptomycin, 100 units $/ \mathrm{ml}$ penicillin, and $2 \mathrm{mM}$ L-glutamine (Gibco (part of
Thermo Fisher Scientific), Carlsbad, CA, USA). Recombinant human GM-CSF (Sigma-Aldrich, Taufkirchen, Germany) was added to UT-7 cells that require the bioactive protein for survival and proliferation, at final concentration of $5 \mathrm{ng} / \mathrm{ml}$. The cell lines were grown in a standard cell culture incubator at $37^{\circ} \mathrm{C}, 100 \%$ relative humidity, and in $5 \% \mathrm{CO}_{2}$. All experiments were performed within six months after cell thawing.

AlamarBlue assay. Cellular proliferation was evaluated using the fluorimetric/colorimetric alamarBlue cell viability assay reagent (Thermo Fisher Scientific, Waltham, Massachusetts, USA) and evaluated with Tecan Sunrise ${ }^{\mathrm{TM}}$ microplate reader (Männedorf, Switzerland). SET-2 or UT-7 cells were plated at 5000 cells/well in 96-well plates with round bottom (Greiner CELSTAR ${ }^{\oplus}$, purchased from Sigma-Aldrich, Taufkirchen, Germany). Cells were treated with inhibitor (or an equivalent volume of vehicle (DMSO)) $24 \mathrm{~h}$ after plating and grown for 24, 48, and $72 \mathrm{~h}$. Following the indicated growth period, alamarBlue was added ( $10 \%$ of culture volume), cells were incubated at $37^{\circ} \mathrm{C} / 100 \%$ relative humidity $/ 5 \% \mathrm{CO}_{2}$ for $5 \mathrm{~h}$ and absorbance was measured at $550 \mathrm{~nm}$ (excitation) and $620 \mathrm{~nm}$ (emission). The manufacturer's recommended formulas were used to calculate final results.

Dye exclusion assay. Trypan blue (Gibco (part of Thermo Fisher Scientific), Carlsbad, California, USA) solution was used for cell viability assay. Briefly, $2 \times 10^{5}$ cells were seeded into $35 \mathrm{~mm}$ diameter 'TPP' Petri dishes (Trasadingen, Switzerland). Cells were treated with inhibitor (or an equivalent volume of vehicle (DMSO)) $24 \mathrm{~h}$ after plating. After 24,48 , and $72 \mathrm{~h}$ the cells were collected, $10 \mu \mathrm{l}$ of cell suspension was mixed with $90 \mu \mathrm{l}$ of $0.4 \%$ Trypan blue and cell viability was analysed with Neubauer haemocytometer (Weber, England) under an Olympus CK40 (Shinjuku, Tokyo, Japan) optical microscope.

\section{Statistical Analysis}

The concentration at which $50 \%$ inhibition (IC50) of cell proliferation occurred was calculated using Excel add-in ED50V10. IBM SPSS Statistics 22.0 software (Armonk, NY, USA) was 
used to perform statistical tests. The data were analyzed using independent sample t-test and one-way analysis of variance (ANOVA), followed by post-hoc Tukey multiple comparison test when appropriate. The data are presented as means \pm standard deviation (SD), and $p<0.05$ was considered significant. Experiments were performed in triplicate and repeated at least three times independently.

\section{RESULTS}

We evaluated the effect of specific cell signaling pathways inhibitors on the viability of SET- 2 cells expressing the JAK2 p.V617F mutation and UT-7 cells harbouring wild-type JAK2. The effect of PI3K/Akt/mTOR, JAK/STAT, and Hedgehog signaling pathways inhibitors was studied as time- and dose-response experiments after 24,48 , and $72 \mathrm{~h}$, at various concentrations.

We found that all specific inhibitors progressively reduced viable cell number as the concentration and exposure duration increased. The proliferative response was observed in both cell lines by trypan blue dye exclusion test and alamarBlue assay. Figures 1 and 2 represent the results of all experiments for each cell line.

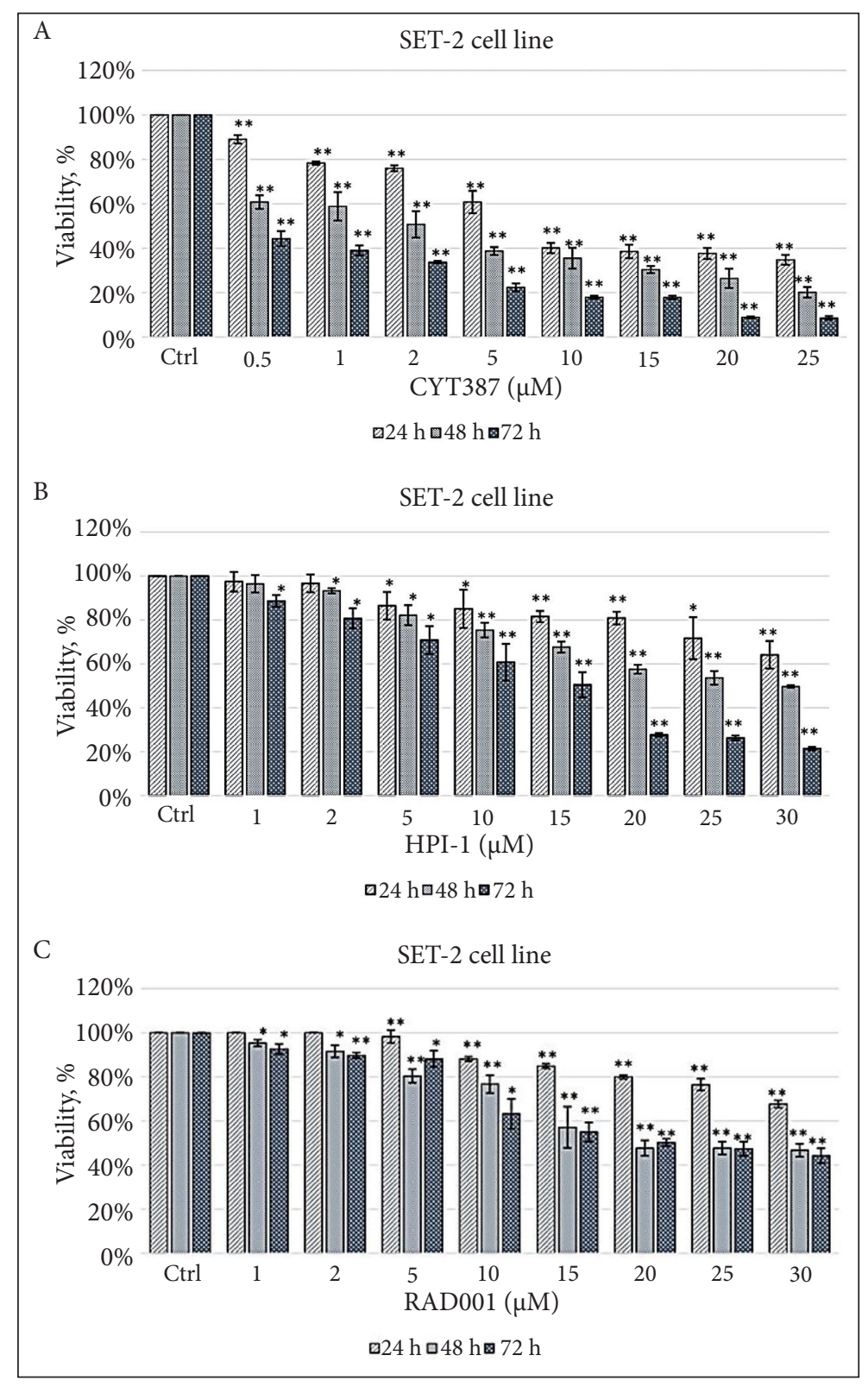

Fig. 1 (A-C). RAD001, CYT387, and HPI-1 decrease SET-2 cell line viability. Cells were treated with various concentrations of inhibitors for 24, 48, and 72 hours. Bar graph represents the fraction of trypan blue-positive inhibitor treated cells. The differences between the control group and treated cells were evaluated using independent sample t-test. Error bars indicate the standard deviation of the mean. Treatments significantly different from the vehicle control at $p<0.05$ are presented as *; ** means $p<0.001$ obtained by the statistical analysis 


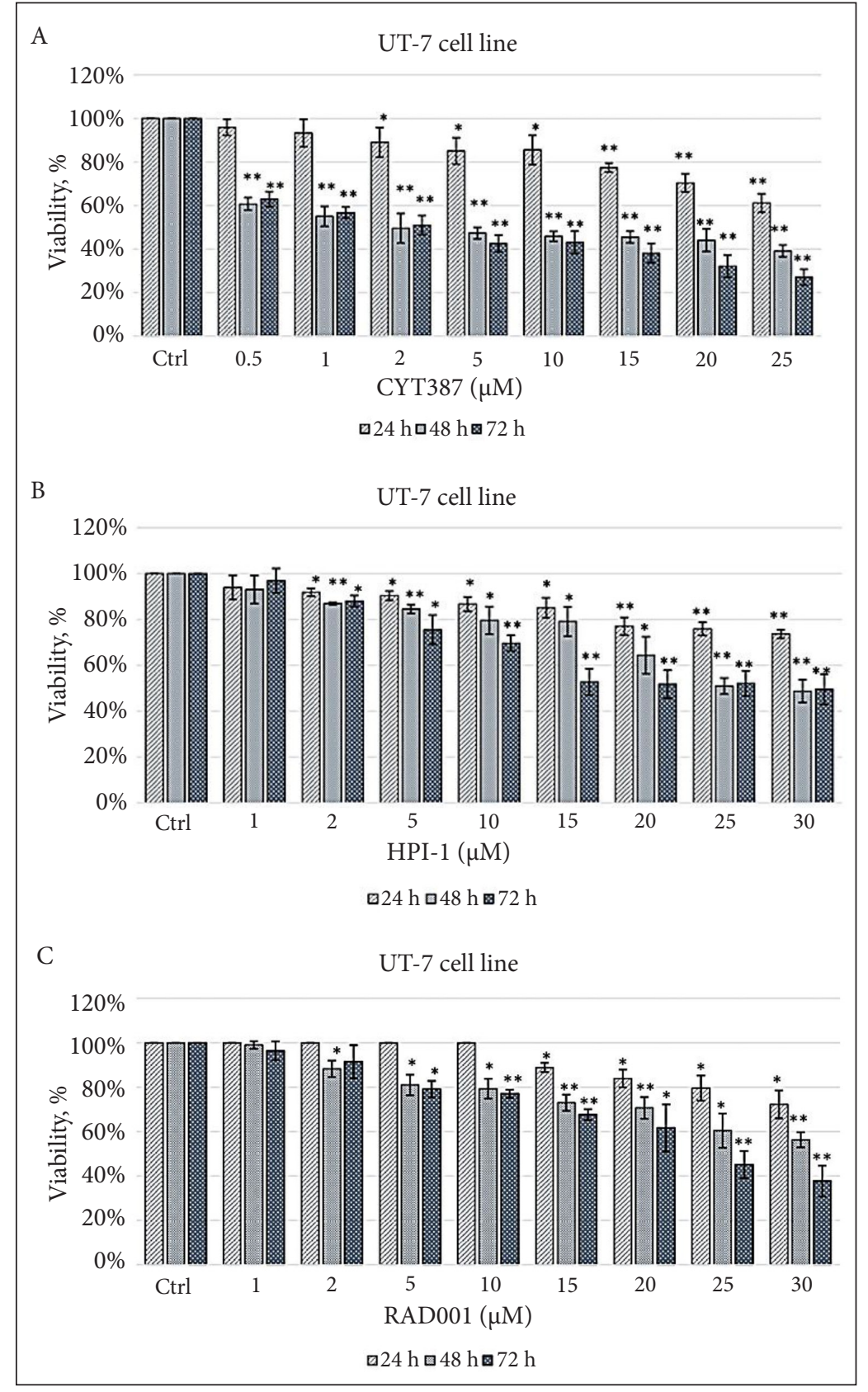

Fig. 2 (A-C). RAD001, CYT387 and HPI-1 decrease UT-7 cell line viability. Cells were treated with various concentrations of inhibitors for 24, 48, and 72 hours. The bar graph represents the fraction of trypan blue-positive inhibitor treated cells. The differences between control group and treated cells were evaluated using independent sample t-test. Error bars indicate the standard deviation of the mean. Treatments significantly different from the vehicle control at $p<0.05$ are presented as *; ** means $p<0.001$ obtained by the statistical analysis
Only the viability data obtained by trypan blue assay in RAD001, CYT387, and HPI-1 are presented in Figs. 1 and 2; alamarBlue assay results were similar.

In this study we aimed to evaluate and compare the response of haematological cell line viability to specific inhibitors of signaling molecules. Therefore, IC50 values for each independent experiment were calculated and IC50 mean values among RAD001, CYT387, and
HPI-1 treatments were analyzed (see Tables 1 and 2). Our data indicate that the cell line expressing JAK2 p.V617F is exquisitely sensitive to CYT387 as a single agent showing proliferation arrest. We found that JAK2 mutated cells were definitely more sensitive to inhibition of the PI3K/Akt/mTOR and Hedgehog pathways than the wild-type counterpart UT-7 cell line. Our data indicate that both cell lines were relatively less sensitive to HPI-1. 
Table 1. The effect of RAD001, CYT387, and HPI-1 inhibitors on the proliferation rate of SET-2 cell line. Table results of the one-way ANOVA and Tukey significance test for multiple comparisons. The data are presented as the mean and standard deviation (SD). The level of significance from the test was $p<0.05$

\begin{tabular}{|c|c|c|c|c|c|c|}
\hline & & $\begin{array}{l}\text { RAD001 mean } \\
\text { IC50 (SD) }\end{array}$ & $\begin{array}{l}\text { CYT387 mean } \\
\text { IC50 (SD) }\end{array}$ & $\begin{array}{l}\text { HPI-1 mean } \\
\text { IC50 (SD) }\end{array}$ & $\begin{array}{c}p \\
\text { value }\end{array}$ & $\begin{array}{c}95 \% \mathrm{CI} \text { of } \\
\text { the difference }\end{array}$ \\
\hline \multicolumn{7}{|c|}{ Trypan blue exclusion assay } \\
\hline \multirow{3}{*}{$24 \mathrm{~h}$} & RAD001 vs CYT387 & $49.00(3.38)$ & $13.72(0.87)$ & & 0.001 & 21.28 to 49.28 \\
\hline & RAD001 vs HPI-1 & $49.00(3.38)$ & & 46.97 & 0.898 & -11.96 to 16.03 \\
\hline & CYT387 vs HPI-1 & & $13.72(0.87)$ & 46.97 & 0.001 & -47.24 to -19.25 \\
\hline \multirow{3}{*}{$48 \mathrm{~h}$} & RAD001 vs CYT387 & $23.28(1.67)$ & $7.12(1.06)$ & & 0.0001 & 13.29 to 19.03 \\
\hline & RAD001 vs HPI-1 & $23.28(1.67)$ & & $26.99(0,12)$ & 0.017 & -6.58 to -0.84 \\
\hline & CYT387 vs HPI-1 & & $7.12(1.06)$ & $26.99(0,12)$ & 0.0001 & -22.74 to -17.00 \\
\hline \multirow{3}{*}{$72 \mathrm{~h}$} & RAD001 vs CYT387 & $22.44(1.27)$ & $0.44(0.24)$ & & 0.0001 & 24.08 \\
\hline & RAD001 vs HPI-1 & $22.44(1.27)$ & & $15.35(0.634)$ & 0.0001 & 5.00 to 9.17 \\
\hline & CYT387 vs HPI-1 & & $0.44(0.24)$ & $15.35(0.634)$ & 0.0001 & -17.00 to -12.83 \\
\hline \multicolumn{7}{|c|}{ alamarBlue test } \\
\hline \multirow{3}{*}{$24 \mathrm{~h}$} & RAD001 vs CYT387 & $4.14(3.01)$ & & & 0.0001 & 4.03 \\
\hline & RAD001 vs HPI-1 & $46.14(5.31)$ & & $54.53(5.98)$ & 0.146 & -19.98 to 3.20 \\
\hline & CYT387 vs HPI-1 & & $13.64(0.54)$ & $54.53(5.98)$ & 0.0001 & -52.48 to -29.30 \\
\hline \multirow{3}{*}{$48 \mathrm{~h}$} & RAD001 vs CYT387 & $26.51(3.61)$ & $7.63(1.02)$ & & 0.0001 & 12.36 to 25.39 \\
\hline & RAD001 vs HPI-1 & $26.51(3.61)$ & & $31.08(2.49)$ & 0.159 & -11.09 to 1.95 \\
\hline & CYT387 vs HPI-1 & & $7.63(1.02)$ & $31.08(2.49)$ & 0.0001 & -29.97 to -16.93 \\
\hline \multirow{3}{*}{$72 \mathrm{~h}$} & RAD001 vs CYT387 & $23.03(1.15)$ & $1.18(0.49)$ & & 0.0001 & 19.62 to 24.07 \\
\hline & RAD001 vs HPI-1 & $23.03(1.15)$ & & $15.93(0.89)$ & 0.0001 & 4.91 to 9.35 \\
\hline & CYT387 vs HPI-1 & & $1.18(0.49)$ & $15.93(0.89)$ & 0.0001 & -16.94 to -12.50 \\
\hline
\end{tabular}

Table 2. The effect of RAD001, CYT387 and HPI-1 inhibitors on the proliferation rate of UT-7 cell line. Table results of the one-way ANOVA and Tukey significance test for multiple comparisons. The d are presented as the mean and standard deviation (SD). The level of significance from test was $p<0.05$

\begin{tabular}{cc|c|c|c|c|c}
\hline & & $\begin{array}{c}\text { RAD001 mean } \\
\text { IC50 (SD) }\end{array}$ & $\begin{array}{c}\text { CYT387 mean } \\
\text { IC50 (SD) }\end{array}$ & $\begin{array}{c}\text { HPI-1 mean } \\
\text { IC50 (SD) }\end{array}$ & $\begin{array}{c}\boldsymbol{p} \\
\text { value }\end{array}$ & $\begin{array}{c}\text { 95\% CI of } \\
\text { the difference }\end{array}$ \\
\hline \multicolumn{7}{c}{ Trypan blue exclusion assay } \\
\hline $24 \mathrm{~h}$ & RAD001 $v s$ CYT387 & $57.63(8.88)$ & $34.36(2.67)$ \\
\hline & RAD001 $v s$ HPI-1 & $57.63(8.88)$ & & 0.007 & 8.50 to 38.05 \\
\hline & CYT387 $v$ HPI-1 & & $57.89(4.28)$ & 0.998 & -15.03 to 14.52 \\
\hline $48 \mathrm{~h}$ & RAD001 $v$ CYT387 & $33.90(4.77)$ & $12.20(0.81)$ & & 0.0001 & 13.46 to 29.94 \\
\hline & RAD001 $v s$ HPI-1 & $33.90(4.77)$ & & $57.89(4.28)$ & 0.222 & -3.17 to 13.31 \\
\hline & CYT387 $v$ HPI-1 & & $12.20(0.81)$ & $57.89(4.28)$ & 0.002 & -24.87 to -8.39 \\
\hline $72 \mathrm{~h}$ & RAD001 $v s$ CYT387 & $24.00(3.34)$ & $9.03(1.40)$ & & 0.001 & 9.13 to 20.81 \\
\hline & RAD001 $v s$ HPI-1 & $24.00(3.34)$ & & $24.27(1.79)$ & 0.988 & -6.11 to 5.56 \\
\hline & CYT387 $v$ HPI-1 & & $9.03(1.40)$ & $24.27(1.79)$ & 0.0001 & -21.09 to -9.41 \\
\hline
\end{tabular}


Table 2. (Continued)

\begin{tabular}{cc|c|c|c|c|c}
\hline & & $\begin{array}{c}\text { RAD001 mean } \\
\text { IC50 (SD) }\end{array}$ & $\begin{array}{c}\text { CYT387 mean } \\
\text { IC50 (SD) }\end{array}$ & $\begin{array}{c}\text { HPI-1 mean } \\
\text { IC50 (SD) }\end{array}$ & $\begin{array}{c}\boldsymbol{p} \\
\text { value }\end{array}$ & $\begin{array}{c}\mathbf{9 5 \%} \text { CI of } \\
\text { the difference }\end{array}$ \\
\hline \multicolumn{7}{c}{ alamarBlue test } \\
\hline $24 \mathrm{~h} \quad$ RAD001 $v s$ CYT387 & $55.80(8.15)$ & $43.12(6.43)$ & & 0.093 & -2.43 to 27.81 \\
\hline & RAD001 $v s$ HPI-1 & $55.80(8.15)$ & & $49.26(1.23)$ & 0.432 & -8.58 to 21.66 \\
\hline & CYT387 $v$ HPI-1 & & $43.12(6.43)$ & $49.26(1.23)$ & 0.471 & -21.27 to 8.97 \\
\hline $48 \mathrm{~h}$ & RAD001 $v$ CYT387 & $32.89(3.44)$ & $11.27(1.03)$ & & 0.0001 & 13.59 to 29.64 \\
\hline & RAD001 $v s$ HPI-1 & $32.89(3.44)$ & & $33.39(4.22)$ & 0.980 & -8.52 to 7.52 \\
\hline & CYT387 $v$ HPI-1 & & $11.27(1.03)$ & $33.39(4.22)$ & 0.0001 & -30.14 to -14.09 \\
\hline $72 \mathrm{~h}$ & RAD001 $v s$ CYT387 & $25.78(2.54)$ & $7.68(1.71)$ & & 0.0001 & 13.66 to 22.53 \\
\hline & RAD001 $v s$ HPI-1 & $25.78(2.54)$ & & $24.14(0.11)$ & 0.529 & -2.79 to 6.07 \\
\hline & CYT387 $v s$ HPI-1 & & $7.68(1.71)$ & $24.14(0.11)$ & 0.0001 & -20.88 to -12.02 \\
\hline
\end{tabular}

\section{DISCUSSION}

Dysregulation of the JAK/STAT pathway represents the central role in the ethiopathogenesis of MPNs. Inhibitors of the JAK2 have proven efficacious, but they do not target the mutated cell clone selectively and their potential activity is constrained by myelotoxicity, indicating that novel therapeutic strategies should be sought. In this regard, we focused on JAK/STAT and alternative signaling pathways such as PI3K/Akt/ mTOR and Hedgehog, with the objective to characterise the efficacy of specific inhibitors in different cellular models, including JAK2 mutated and wild-type JAK2 cells. The aim of this study was to determine the anti-proliferative activity of PI3K/Akt/mTOR, JAK/STAT and Hedgehog signaling inhibitors. We evaluated the activity of RAD001, CYT387 and HPI-1 inhibitors that are currently under evaluation in several trials (Wang et al., 2009; Guglielmelli et al., 2011; Pardanani et al., 2013; Pardanani et al., 2015). After treatment, SET-2 cells expressing JAK2 mutation showed increased sensitivity toward compounds, compared to wild-type JAK2 cell line.

CYT387 inhibited proliferation of cells expressing JAK2 mutation with a lowest IC50 compared to RAD001 and HPI-1 inhibitors. Our findings acknowledged Pardanani et al. (2009) study results where the rate of JAK2 p.V617F mutation positive cell line proliferation, after CYT387 exposure, was analysed (Pardanani et al., 2009). Our data indicate that CYT387 was considerably less potent at inhibiting growth of UT-7 cells, which was probably due to its restricted kinase inhibitory profile.

Until now, the potential relevance of targeting PI3K/Akt/mTOR pathway with specific inhibitors has been explored (Bogany et al., 2013; Bartalucci et al., 2017). The results of our study confirm previous reports, suggesting that RAD001 has an anti-proliferative effect on cells carrying JAK2 p.V617F mutation. However, the concentration at which $50 \%$ inhibition of SET-2 cell proliferation occurred was slightly greater compared to Bogani et al. (2013) results $(23.28 \pm 1.67 \mu \mathrm{M} v s 17 \pm 0.3 \mu \mathrm{M}$ after $48 \mathrm{~h}$ of compound exposure) (Bogani et al., 2013). We are not able to provide clear explanations for such differences, but, in our opinion, this could be due to different cell cultivation conditions, the types of plastics, the assays used for cell viability determination, and a number of other variables.

To date, preclinical data on the potential role of the Hedgehog pathway in MPN are limited. To the best of our knowledge, only in one study the expression of Hedgehog signaling molecules were shown to be increased up to 100fold in granulocytes isolated from patients with MPNs compared with control granulocytes 
(Bhagwat et al., 2013). Therefore, cell-based in vitro studies with the Hedgehog signaling pathway inhibitors effect on MPN cells are warranted. This was the first study to address the antiproliferative effect of HPI-1 on cell line carrying JAK2 p.V617F. Our results suggest that HPI-1 exerts an anti-proliferative effect on SET-2 cell line. We found SET-2 cells significantly more sensitive to HPI-1 inhibitor compared to wildtype JAK2 UT-7 cell line. Therefore, our study results support the involvement of the Hedgehog signaling pathway in MPN pathogenesis.

Overall, there is significant interest in traditional and experimental agents acting on the JAK/STAT, PI3K/Akt/mTOR, and Hedgehog signaling pathways. Unfortunately, the results of our study and modern MPN treatment protocols are difficult to compare. All agents used in this study are currently undergoing promising clinical and preclinical testing. The only thing that could be done is to compare preclinical in vitro results with our data and indicate directions for future research. Targeting the mentioned pathways in MPN is clinically relevant and suggests the opportunity of further clinical experimentation with specific inhibitors as a single agent, perhaps with the use of different drug dosage and time schedules, or in combination with other novel molecules.

\section{CONCLUSIONS}

These in vitro data indicate that PI3K/Akt/ mTOR, JAK/STAT, and Hedgehog inhibitors have potent anti-proliferative efficacy. Moreover, our findings show that drug-mediated inhibition of PI3K/Akt/mTOR and Hedgehog signaling is efficacious against MPN cells with mutated JAK2. Concurrent targeting of the alternative pathways may represent new therapeutic strategies. We have to admit that the lack of proteome and post-genomic analysis is the limitation of our study. Taken together, realisation of this new treatment opportunity may require direct screening of $\mathrm{PI} 3 \mathrm{~K} / \mathrm{Akt} / \mathrm{mTOR}$, JAK/STAT, and Hedgehog signaling molecule activity at the gene and protein level in cell- based MPN models. Further work is warranted to develop the treatment regimen, safe and effective agent dose confirmation in controlled MPN patient's group.

\section{Conflict of interest statement}

The authors declare that they have no competing interests.

Received 22 March 2021

Accepted 31 March 2021

\section{References}

1. Akada H, Yan D, Zou H, Fiering S, Hutchison RE, Mohi MG. Conditional expression of heterozygous or homozygous Jak2 V617F from its endogenous promoter induces a polycythemia vera-like disease. Blood. 2010; 115: 3589-97.

2. Andrikovics $\mathrm{H}$, Krahling $\mathrm{T}$, Balassa $\mathrm{K}$, Halm G, Bors A, Koszarska M, et al. Distinct clinical characteristics in myeloproliferative neoplasms with calreticulin mutations. Haematologica. 2014; 99: 1-30.

3. Araki M, Yang $Y$, Masubuchi N, Hironaka $Y$, Takei H, Morishita S, et al. Activation of the thrombopoietin receptor by mutant calreticulin in CALR-mutant myeloproliferative neoplasms. Blood. 2016; 127: 1307-16.

4. Bartalucci N, Tozzi L, Bogani C, Martinelli S, Rotunno G, Villeval JL, Vannucchi AM. Cotargeting the PI3K/mTOR and JAK2 signalling pathways produces synergistic activity against myeloproliferative neoplasms. J Cell Mol Med. 2017; 17: 1385-96.

5. Beer PA, Campbell P, Scott LM, Bench AJ, Erber WN, Bareford D, et al. MPL mutations in myeloproliferative disorders: analysis of the PT-1 cohort. Blood. 2008; 112: 141-9.

6. Bhagwat N, Keller MD, Rampal RK, Shank K, de Stanchina E, Rose K, et al. Improved efficacy of combination of JAK2 and hedgehog 
inhibitors in myelofibrosis. Proceedings of the 55th ASH Annual Meeting and Exposition; 2013 December 7; New Orleans, LA, USA.

7. Bogani C, Bartalucci N, Martinelli S, Tozzi L, Guglielmelli P, Bosi A, Vannucchi AM. mTOR inhibitors alone and in combination with JAK2 inhibitors effectively inhibit cells of myeloproliferative neoplasms. PLoS One. 2013; 8: e54826.

8. Bumm TG, Elsea C, Corbin AS, Loriaux M, Sherbenou D, Wood L, et al. Characterization of murine JAK2V617F-positive myeloproliferative disease. Cancer Res. 2006; 66: 11156-65.

9. Campbell V, Copland M. Hedgehog signaling in cancer stem cells: a focus on hematological cancers. Stem Cells Cloning. 2015; 8: 27-8.

10. Cervantes F, Kiladjian JJ, Niederwieser D, Sirulnik A, Stalbovskaya V, McQuity M, et al. Long-term safety, efficacy, and survival findings from comfort-II, a phase 3 study comparing ruxolitinib with best available therapy (BAT) for the treatment of myelofibrosis (MF). Blood. 2012; 120: 801.

11. Chachoua I, Pecquet C, El-Khoury M, Nivarthi H, Albu RI, Marty C, et al. Thrombopoietin receptor activation by myeloproliferative neoplasm associated calreticulin mutants. Blood. 2016; 127: 1325-35.

12. Dupont S, Masse A, James C, Teyssandier I, Lecluse Y, Larbret F, et al. The JAK2 V617F mutation triggers erythropoietin hypersensitivity and terminal erythroid amplification in primary cells from patients with polycythemia vera. Blood. 2007; 110: 1013-21.

13. Engelman JA. Targeting PI3K signalling in cancer: opportunities, challenges and limitations. Nat Rev Cancer. 2009; 9: 550-2.

14. Gao Y, Yuan CY, Yuan W. Will targeting PI3K/ Akt/mTOR signaling work in hematopoietic malignancies? Stem Cell Investig. 2016; 3: 31.

15. Grimwade LF, Happerfield L, Tristram C, McIntosh G, Rees M, Bench AJ, et al. Phospho-STAT5 and phospho-Akt expression in chronic myeloproliferative neoplasms. $\mathrm{Br} \mathrm{J}$ Haematol. 2009; 147: 495-6.

16. Grinfeld J, Nangalia J, Green AR. Molecular determinants of pathogenesis and clinical phenotype in myeloproliferative neoplasms. Haematologica. 2017; 102: 7-17.

17. Guglielmelli P, Barosi G, Rambaldi A, Marchioli R, Masciulli A, Tozzi L, et al. Safety and efficacy of everolimus, a mTOR inhibitor, as single agent in a phase $1 / 2$ study in patients with myelofibrosis. Blood. 2011; 118: 2069-76.

18. Harrison C, Kiladjian JJ, Al-Ali HK, Gisslinger H, Waltzman R, Stalbovskaya V, et al. JAK inhibition with ruxolitinib versus best available therapy for myelofibrosis. N Engl J Med. 2012; 366: 787-98.

19. Hyman JM, Firestone AJ, Heine VM, Zhao Y, Ocasio CA, Han K, et al. Small-molecule inhibitors reveal multiple strategies for Hedgehog pathway blockade. Proc Natl Acad Sci USA. 2009; 106: 14132-7.

20. James C, Ugo V, Le Couedic JP, Staerk J, Delhommeau $\mathrm{F}$, Lacout $\mathrm{C}$, et al. A unique clonal JAK2 mutation leading to constitutive signalling causes polycythaemia vera. Nature. 2005; 434: 1144-8.

21. Klampfl T, Gisslinger H, Harutyunyan AS, Nivarthi H, Rumi E, Milosevic JD, et al. Somatic mutations of calreticulin in myeloproliferative neoplasms. N Engl J Med. 2013; 369: 2379-90.

22. Marty C, Lacout C, Martin A, Hasan S, Jacquot S, Birling MC, et al. Myeloproliferative neoplasm induced by constitutive expression of JAK2V617F in knock-in mice. Blood. 2010; 116: 783-7.

23. Mullally A, Lane SW, Ball B, Megerdichian C, Okabe R, Al-Shahrour F, et al. Physiological Jak2V617F expression causes a lethal myeloproliferative neoplasm with differential effects on hematopoietic stem and progenitor cells. Cancer Cell. 2010; 17: 584-6.

24. Nangalia J, Massie CE, Baxter EJ, Nice FL, Gundem G, Wedge DC, et al. Somatic CALR 
mutations in myeloproliferative neoplasms with nonmutated JAK2. N Engl J Med. 2013; 19: 2391-405.

25. Pardanani A, Abdelrahman RA, Finke C, Lasho TT, Begna KH, Al-Kali A, et al. Genetic determinants of response and survival in momelotinib-treated patients with myelofibrosis. Leukemia.2015; 29: 741-4.

26. Pardanani A, Laborde RR, Lasho TL, Finke C, Begna K, Al-Kali A, et al. Safety and efficacy of CYT387, a JAK1 and JAK2 inhibitor, in myelofibrosis. Leukemia.2013; 27: 1322-7.

27. Pardanani A, Lasho T, Smith G, Burns CJ, Fantino E, Tefferi A. CYT387, a selective JAK1/ JAK2 inhibitor: in vitro assessment of kinase selectivity and preclinical studies using cell lines and primary cells from polycythemia vera patients. Leukemia. 2009; 23: 1441-5.

28. Quintas-Cardama A, Vaddi K, Liu P, Manshouri T, Li J, Scherle PA, et al. Preclinical characterization of the selective JAK1/2 inhibitor INCB018424: therapeutic implications for the treatment of myeloproliferative neoplasms. Blood. 2010; 115: 3109-17.

29. Rimkus TK, Carpenter RL, Qasem S, Chan M, Lo HW. Targeting the Sonic Hedgehog signaling pathway: review of Smoothened and GLI inhibitors. Cancers (Basel). 2016; 8: 22.

30. Rotunno G, Mannarelli C, Guglielmelli P, Pacilli A, Pancrazzi A, Pieri L, et al. Impact of calreticulin mutations on clinical and hematological phenotype and outcome in essential thrombocythemia. Blood. 2014; 123: 1552-5.

31. Shide K, Shimoda HK, Kumano T, Karube K, Kameda T, Takenaka K, et al. Development of ET, primary myelofibrosis and PV in mice expressing JAK2 V617F. Leukemia. 2008; 22: 87-5.
32. Tibes R, Mesa RA Targeting hedgehog signaling in myelofibrosis and other hematologic malignancies. J Hematol Oncol.2014; 7: 18.

33. Vainchenker W, Delhommeau F, Constantinescu SN, Bernard OA. New mutations and pathogenesis of myeloproliferative neoplasms. Blood. 2011; 118: 1723-35.

34. Vannucchi AM, Guglielmelli P, Tefferi A. Advances in understanding and management of myeloproliferative neoplasms. CA Cancer J Clin. 2009; 59: 171-1.

35. Vannucchi AM, Bogani C, Bartalucci N, Tozzi L, Martinelli S, Guglielmelli P, et al. Inhibitors of PI3K/Akt and/or mTOR inhibit the growth of cells of myeloproliferative neoplasms and synergize with JAK2 inhibitor and interferon. Blood. 2011; 118: 3835.

36. Verstovsek S, Mesa RA, Gotlib J, Levy RS, Gupta V, DiPersio JF, et al._Efficacy, safety and survival with ruxolitinib treatment in patients with myelofibrosis: results of a median 2-year follow-up of COMFORT-I. Haematologica. 2013; 98: 1865-71.

37. Wang Y, Fiskus W, Chong DG, Buckley KM, Natarajan K, Rao R, et al. Cotreatment with panobinostat and JAK2 inhibitor TG101209 attenuates JAK2V617F levels and signaling and exerts synergistic cytotoxic effects against human myeloproliferative neoplastic cells. Blood. 2009; 114: 5024-33.

38. Zingariello M, Martelli F, Ciaffoni F, Masiello F, Ghinassi B, D'Amore E, et al. Characterization of the TGF- $\beta 1$ signaling abnormalities in the Gatallow mouse model of myelofibrosis. Blood. 2013; 121: 3345-63. 
Roberta Vadeikiené, Aistė Savukaitytė, Danguolè Laukaitienè, Rasa Ugenskienè, Elona Juozaitytė

MTOR, JAK/STAT IR HEDGEHOG SIGNALO PERDAVIMO INHIBITORIŲ POVEIKIO ONKOHEMATOLOGINIŲ LĄSTELIŲ LINIJŲ PROLIFERACIJAI TYRIMAS

\section{Santrauka}

Klasikinems $B C R / A B L$ neigiamoms mieloproliferacinèms ligoms (MPL) būdinga nuolat aktyvi JAK/ STAT signalo perdavimo sistema. Nustatyta, kad klinikinèje praktikoje taikomi JAK2 inhibitoriai nèra specifiniai mutacijos atveju ir nepakankamai slopina neoplastinę kloninę hematopoezę, todèl būtina ieškoti naujų terapinių MPL galimybių. Potencialus gydymo taikinys yra ląstelès signalo perdavimo sistemos - PI3K/Akt/mTOR ir Hedgehog. Šios studijos tikslas - nustatyti ir palyginti specifinių JAK/STAT, $\mathrm{PI} 3 \mathrm{~K} / \mathrm{Akt} / \mathrm{mTOR}$ bei Hedgehog signalo perdavimo inhibitorių poveikị hematologinèms ląstelių linijoms. Tyrimo metu buvo naudojamos SET-2 ląstelès, turinčios JAK2 p.V617F mutaciją, ir UT-7 ląstelių linija, pasižyminti laukinio tipo JAK2. Specifinių signalo perdavimo inhibitorių poveikis ištirtas atsižvelgiant $\mathfrak{i}$ ekspozicijos laiką ir dozes. Ląstelių gyvybingumas nustaytas Tripano melio ir alamarBlue testais. IC50 reikšmès panaudotos ịvertinant inhibitorių efektyvumą. Statistinè analizè atlikta pagal t-testą. Nustatytas statistiškai reikšmingas skirtumas tarp tiriamų grupių, kai $p<0,05$. Tyrimo metu nustatyta, kad visi specifiniai inhibitoriai mažino ląstelių gyvybingumą didejjant koncentracijai ir ekspozicijos laikui. Ląstelių, turinčių JAK2 mutaciją, proliferacija sutrikdyta reikšmingai mažesnèmis inhibitorių koncentracijomis, palyginti su ląstelemis, neturinčiomis JAK2 mutacijos. Šio in vitro tyrimo rezultatai rodo, kad JAK/STAT ir alternatyvūs PI3K/ Akt/mTOR bei Hedgehog inhibitoriai pasižymi antiproliferaciniu poveikiu. Tolesniuose tyrimuose būtina išanalizuoti PI3K/Akt/mTOR, JAK/STAT ir Hedgehog signalinių molekulių aktyvumą genų ir baltymų lygmeniu panaudojant MPL ląstelių modelius.

Raktažodžiai: mieloproliferacinès ligos (MPL), JAK/STAT, PI3K/Akt/mTOR, Hedgehog, signalo perdavimo sistemos, ląstelių linijos 